\title{
Communication
}

\section{Demographic Traits Variation in a Pyrenean Newt (Calotriton asper) among Lacustrine and Stream Populations}

\author{
Sebastià Camarasa ${ }^{1, * \mathbb{C}}$, Neus Oromi ${ }^{1}$, Delfí Sanuy ${ }^{1,2, *}$ and Fèlix Amat ${ }^{3}$ \\ 1 Departament de Ciència Animal, Secció de Fauna Silvestre, Universitat de Lleida, Alcalde Rovira Roure 191, \\ 25198 Lleida, Catalonia, Spain; neusoromi@gmail.com \\ 2 Centre Tecnològic Forestal de Catalunya, Ctra. St. Llorenç de Morunys km 2, 25280 Solsona, Catalonia, Spain \\ 3 Àrea d'Herpetologia, BiBIO, Museu de Granollers-Ciències Naturals, Palaudàries 102, \\ 08402 Granollers, Catalonia, Spain; felixamat09@gmail.com \\ * Correspondence: sebastiacamarasa@gmail.com (S.C.); dsanuy@ca.udl.cat (D.S.); Tel.: +34-620-600-173 (S.C.)
}

Received: 26 October 2020; Accepted: 10 December 2020; Published: 12 December 2020

\begin{abstract}
Demographic traits were analyzed in the Pyrenean brook newt (Calotriton asper) to evaluate whether its variability responds to the adaptation to the different habitats. In this study, life history traits of Calotriton asper were studied in nine populations living in two different kinds of habitats in the Pyrenees mountains: lakes and streams. Skeletochronology was used to determine age structure and different traits such as age at maturity and longevity. Age structure was different between populations and sexes. The two lacustrine populations, with facultative pedomorphosis, attained their maturity earlier. Age at sexual maturity ranged from 4 to 9 years and in some populations was similar between sexes while in others, females matured at younger ages than males. Maximum longevity varied from 7 to 35 years among populations and was correlated with the age at sexual maturity. Body size differed among populations, was sexually dimorphic, and this disparity was not related to the kind of habitat. The maximum size was found in the lacustrine population but exhibited high variation between populations. The results obtained show a significant variability between sexes and populations, in age and body size structure of Calotriton asper that did not depend on the habitat.
\end{abstract}

Keywords: age structure; Calotriton asper; habitat type; demography; variability; evolution and body size

\section{Introduction}

Processes such as growth, development, or reproduction constitute the elements of the life history of an organism, each biological cycle being unique and vital [1]. The life history of an organism is variable within the limits of the individual's genotype and their phenotypic expression in different environments can vary, it is known as phenotypic plasticity [2]. In amphibians, phenotypic plasticity is especially widespread promoting a wide diversity of life cycles that can be observed, for example in newts and salamanders. This diversity is the result of the interaction between costs and benefits of the reproduction and development in the aquatic and terrestrial environments [3].

Life history traits in amphibians are strongly linked through trade-offs, such as age at maturity, longevity, and age-size relationship [4]. These life history traits can vary due to many factors such as climatic conditions, trophic resources, predator vs. prey interactions, or interspecific competition [5]. Besides that, these different environmental conditions, such as between lakes and streams, cause variability and promote ecological diversification [6]. The expression of a trait is determined by genetic factors, environmental influences, and interactions between genotype and environment [7]. Related to this, sexual dimorphism is determined by the balance and interaction of multiple selective forces [8]. For example, it may allow the 
reduction of intraspecific competition through ecological, morphological, or behavioral specializations between the sexes. Therefore, differences in body size may indicate a sexual selection or it may be the consequence of competition for food resources [9-11]. On the other hand, local environmental conditions may explain differences in body length [12]. The Pyrenean newt (Calotriton asper) is an endemic newt of the mountains of the Pyrenees, primarily lives in streams, although it has secondarily colonized high mountains lakes [13]. In order urodele, growth rates tend to be highest during the larval and juvenile stages [14]. In the case of the Calotriton asper it has been suggested that the sexes may differ in body size and other traits, influenced by ecological factors, including climatic conditions between each locality [15]. For example, Calotriton asper at some lacustrine localities exhibits facultative pedomorphosis $[16,17]$.

The variation in body sizes and life history traits of the Calotriton asper was previously described in several populations at different habitat conditions [15,18-20]. For example, sexual dimorphism was more strongly expressed in the Central Pyrenean populations (high altitude) where females showed longer tails and smaller heads, while males had more robust tails and higher body weights compared with the Prepyrenees populations (middle altitude) [15]. Another study found that body lengths were higher for surface populations than the subterranean populations [20]. The variety of habitats and the effect of glacial and interglacial periods in the Pyrenees make it a natural laboratory for biogeographic, evolutionary, and ecological studies of mountain fauna such as Calotriton asper [21]. The main goal of this study is to analyze the effect of different habitat types (lacustrine vs. rheophilous) on the demographic characteristics of Calotriton asper. To achieve this, we evaluated life history traits such as body size, age structure, age at sexual maturity, and longevity in six torrent localities and three lacustrine localities of the species.

\section{Materials and Methods}

A total of 399 adult newts were sampled in nine populations (three lakes and six streams) along the southern slope of the Pyrenean mountains, from 2012 to 2015 (Figure 1, Table 1). The main characteristic of the streams is that their hydrological regime is determined by the pattern of snowfall. Consequently, the flow has an extraordinary seasonal variability, with maximums of spring associated with the melting, and the minimums in summer, when in some cases they can dry up. The other kind of habitat we analyzed was high mountain lakes of glacial origin [22]. The main characteristic of the lakes is that they suffer a stratification inversion of the water under the ice layer in winter. The densest waters $\left(4^{\circ} \mathrm{C}\right)$ fall to the bottom and the cold waters remain on the surface. This ice sheet can last several months [23]. Individuals were captured by hand, sexed based on the external morphology of the cloacal area, the newts were sexed based on sexual secondary characters: pointed cloacal protuberance in females and round and bulbous cloaca in males. The snout to the rear margin of the cloaca length (SVL) was measured using a digital caliper with a $0.1 \mathrm{~mm}$ of precision by the same person (F. Amat). Minimum size at sexual maturity was also estimated for each sex and population, as the minimum SVL of sexually mature individuals, age at maturity, as the minimum number of lines of arrested growth LAGs counted in the reproductive individuals and longevity, as the maximum number of LAGs counted in the sexually mature individuals. The authorization numbers for scientific capture of the Government of Aragón, Spain (500201/24/2015/2747; 500210/24/2014/491; 500201/24/2012/12145). These authorizations certifying that the conditions established are approved by the Ethics Committee for this project.

Skeletochronological methods were used to estimate the individual age, and to infer age at sexual maturity and longevity for each sex and population using the protocols described [24,25]. Skeletonchronology, with precise age determinations, is widely applied to the study of sexual maturity and longevity in amphibians [24,26]. The largest toe of the left hind limb was removed and stored in $70 \%$ alcohol and the wound was disinfected. Bones were decalcified in 3\% nitric acid between 35 and $75 \mathrm{~min}$, cleaned by water for $1 \mathrm{~h}$, and placed in phosphate-buffered saline and sucrose $30 \%$ for $48 \mathrm{~h}$ at $4{ }^{\circ} \mathrm{C}$. Cross-sections $(14-16 \mu \mathrm{m})$ were obtained with a freezing microtome and stained with Ehrlich's hematoxylin between 21 and $40 \mathrm{~min}$. The age of each individual was determined by counting 
LAGs in the diaphysis of the periosteal bone using a light microscope at $100 \times$ and $400 \times$ magnifications. The analysis of growth marks was done by S. Camarasa and N. Oromi. Taking into account that in each individual all sections were reviewed in detail and no double growth lines were found, it was estimated that each LAG is one year.

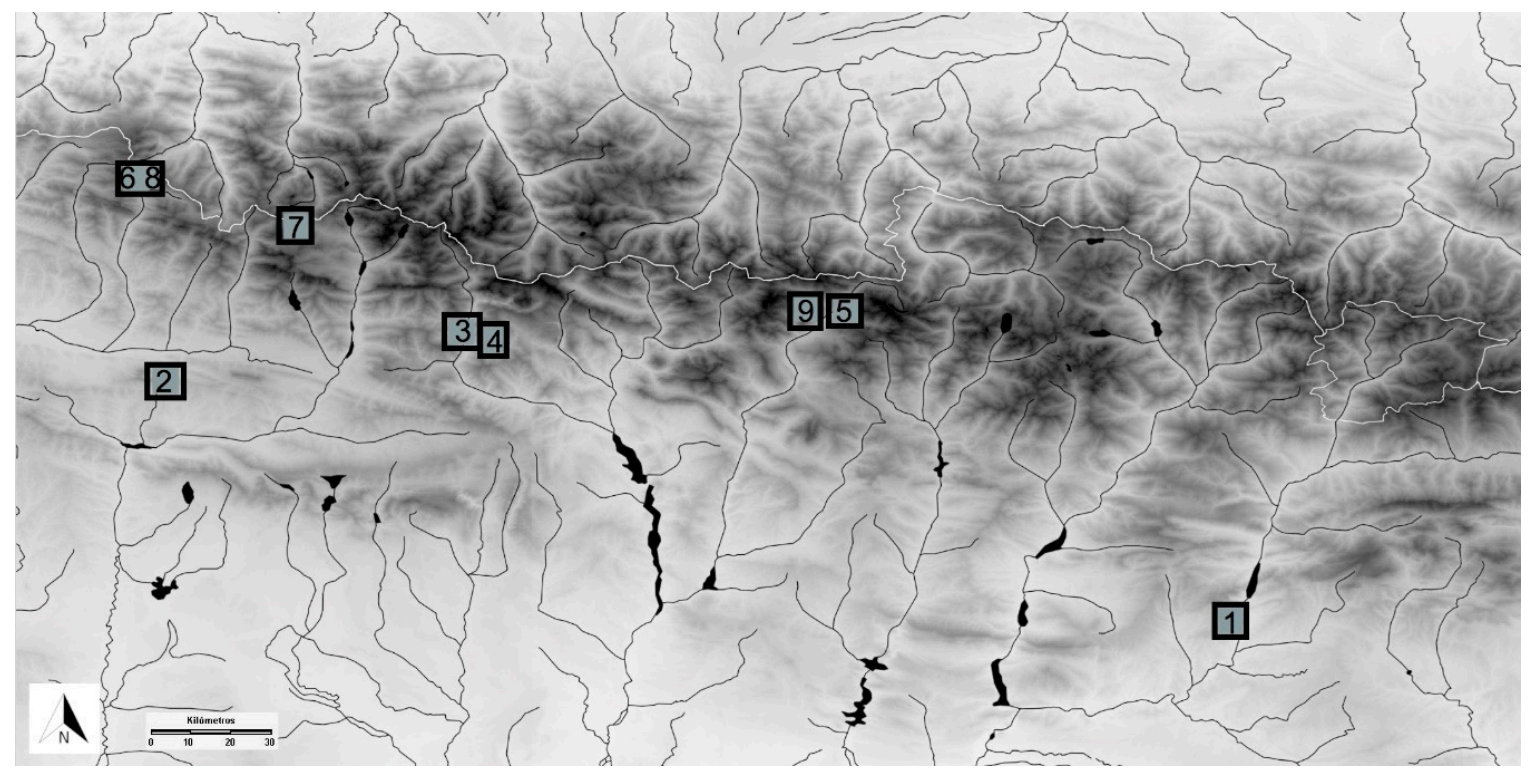

Figure 1. Localization of the sampled localities of Calotriton asper populations. Stream populations: 1 Peramola; 2 San Juan de la Peña; 3 Sarvisé; 4 Oto; 5 Benasc; 6 Barranc Acherito. Lacustrine populations: 7 Espeluciecha; 8 Acherito; 9 Perramó. See Table 1 for details on each locality.

Table 1. Latitude, longitude, altitude, and number of individuals (339 in total) for each locality and habitat.

\begin{tabular}{cccccc}
\hline Habitat & Locality & Latitude & Longitude & Altitude & $n$ \\
\hline \multirow{5}{*}{ Stream } & Peramola & $42^{\circ} 4^{\prime} 17.17^{\prime \prime} \mathrm{N}$ & $1^{\circ} 16^{\prime} 30.98^{\prime \prime} \mathrm{E}$ & 592 & 28 \\
& San Juan de la Peña & $42^{\circ} 30^{\prime} 26.94^{\prime \prime} \mathrm{N}$ & $0^{\circ} 40^{\prime} 0.16^{\prime \prime} \mathrm{W}$ & 1215 & 38 \\
& Sarvisé & $42^{\circ} 34^{\prime} 51.90^{\prime \prime} \mathrm{N}$ & $0^{\circ} 4^{\prime} 17.70^{\prime \prime} \mathrm{W}$ & 122 & 38 \\
& Oto & $42^{\circ} 35^{\prime} 47.47^{\prime \prime} \mathrm{N}$ & $0^{\circ} 7^{\prime} 42.56^{\prime \prime} \mathrm{W}$ & 916 & 44 \\
& Benasc & $42^{\circ} 38^{\prime} 2.23^{\prime \prime} \mathrm{N}$ & $0^{\circ} 34^{\prime} 25.21^{\prime \prime} \mathrm{E}$ & 1600 & 37 \\
\multirow{3}{*}{ Lake } & Barranc de Acherito & $42^{\circ} 52^{\prime} 27.81^{\prime \prime} \mathrm{N}$ & $0^{\circ} 43^{\prime} 18.64^{\prime \prime} \mathrm{W}$ & 1525 & 47 \\
& Espeluciecha & $42^{\circ} 47^{\prime} 18.06^{\prime \prime} \mathrm{N}$ & $0^{\circ} 25^{\prime} 47.93^{\prime \prime} \mathrm{W}$ & 1955 & 52 \\
& Acherito & $42^{\circ} 52^{\prime} 45.52^{\prime \prime} \mathrm{N}$ & $0^{\circ} 42^{\prime} 27.48^{\prime \prime} \mathrm{W}$ & 1872 & 44 \\
\hline
\end{tabular}

To test for differences in age structure among populations, we performed a two-way ANOVA on medium age using sex and populations as factors. Besides, we have a test for body size differences among populations taking into account sexual dimorphism. Thus, two-way ANOVA on mean body size was conducted using sex and populations as factors. Pearson correlation was done to test for relationships between age at sexual maturity and longevity. All analyses were done using JMP Pro 14 [27], (alpha $=0.05)$ on 10 log-transformed variables age and SVL.

\section{Results}

Populations of Calotriton asper exhibited significant differences between sexes, males and females, in age structure at intrapopulation $\left(\mathrm{F}_{1381}=8.667, p=0.003\right)$ and interpopulation level $\left(\mathrm{F}_{8381}=74.902\right.$, $p<0.001$ ). Three examined populations, two lacustrine (Acherito, Perramó) and one stream-dwelling (Barranc de Acherito) had a young age structure (Figure 2, Table 2). However, we found a significant 
interaction between these two factors (sex and locality), thus reflecting that sexual differences in age structure changed over populations $\left(\mathrm{F}_{8381}=2.470, p=0.013\right)$ (Table 3$)$. Nevertheless, the sexual effect on demography was unrelated to the habitat (Table 2): given that the three lacustrine populations showed three different patterns, and of the six rheophilous populations, three of these showed older males than females and the other three the opposite pattern (Figure 2, Table 2).

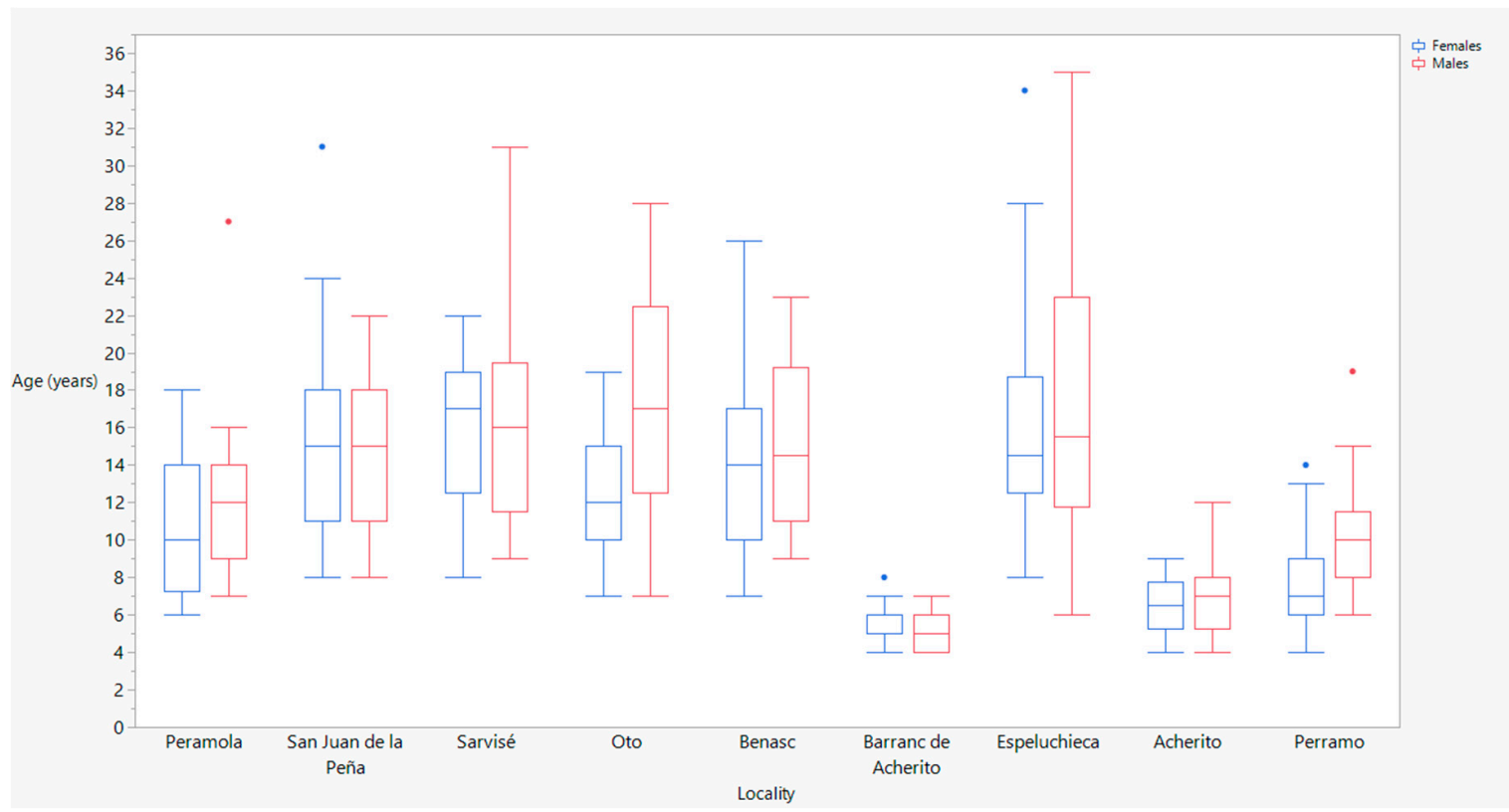

Figure 2. Box-plot of the age structure of the newts for each locality and sex. The 1st Quartile (values up to the first $25 \%$ of sample) lower box limit and the 3rd Quartile (values up to $75 \%$ of sample) upper box limit. Vertical stripes outside the box identify the maximum and minimum values. The extreme cases are represented by circles.

Table 2. Descriptive statistics for age and snout-vent length (SVL) for each sex, locality, and habitat, ES: standard error.

\begin{tabular}{|c|c|c|c|c|c|c|c|c|c|}
\hline \multirow[b]{2}{*}{ Habitat } & \multirow[b]{2}{*}{ Locality } & \multirow[b]{2}{*}{ Sex } & \multirow[b]{2}{*}{$n$} & \multicolumn{3}{|c|}{ Age (Years) } & \multicolumn{3}{|c|}{ SVL (mm) } \\
\hline & & & & Minimum & Maximum & Median & Minimum & Maximum & Mean \pm ES \\
\hline \multirow{12}{*}{ Stream } & \multirow{2}{*}{ Peramola } & Females & 16 & 6 & 18 & 10.0 & 52.3 & 68.8 & $59.0 \pm 1.1$ \\
\hline & & Males & 12 & 7 & 27 & 12.0 & 53.2 & 65.9 & $58.5 \pm 1.3$ \\
\hline & \multirow{2}{*}{$\begin{array}{l}\text { San Juan de } \\
\text { la Peña }\end{array}$} & Females & 19 & 8 & 31 & 15.0 & 54.8 & 70.3 & $61.4 \pm 0.9$ \\
\hline & & Males & 19 & 8 & 22 & 15.0 & 59.7 & 70.8 & $65.9 \pm 0.6$ \\
\hline & \multirow{2}{*}{ Sarvisé } & Females & 17 & 8 & 22 & 17.0 & 51.9 & 58.6 & $57.2 \pm 0.6$ \\
\hline & & Males & 21 & 9 & 31 & 16.0 & 57.9 & 67.2 & $62.7 \pm 0.5$ \\
\hline & \multirow{2}{*}{ Oto } & Females & 23 & 7 & 19 & 12.0 & 50.1 & 59.1 & $54.5 \pm 0.6$ \\
\hline & & Males & 21 & 7 & 28 & 17.0 & 51.1 & 62.6 & $55.3 \pm 0.6$ \\
\hline & \multirow{2}{*}{ Benasc } & Females & 19 & 7 & 26 & 14.0 & 56.4 & 71.3 & $63.7 \pm 0.9$ \\
\hline & & Males & 18 & 9 & 23 & 14.5 & 55.7 & 68.5 & $64.8 \pm 0.8$ \\
\hline & \multirow{2}{*}{$\begin{array}{c}\text { Barranc de } \\
\text { Acherito }\end{array}$} & Females & 20 & 4 & 8 & 5.0 & 63.8 & 77.6 & $73.6 \pm 0.8$ \\
\hline & & Males & 27 & 4 & 7 & 5.0 & 53.9 & 74.5 & $68.9 \pm 0.9$ \\
\hline \multirow{6}{*}{ Lake } & \multirow{2}{*}{ Espeluchieca } & Females & 26 & 8 & 34 & 14.5 & 53.1 & 82.7 & $64.4 \pm 1.4$ \\
\hline & & Males & 26 & 6 & 35 & 15.5 & 58.7 & 76.2 & $64.7 \pm 1.0$ \\
\hline & \multirow[b]{2}{*}{ Acherito } & Females & 12 & 4 & 9 & 6.5 & 56.0 & 68.0 & $61.0 \pm 1.1$ \\
\hline & & Males & 32 & 4 & 12 & 7.0 & 56.0 & 67.0 & $63.0 \pm 0.5$ \\
\hline & \multirow{2}{*}{ Perramó } & Females & 34 & 4 & 14 & 7.0 & 58.0 & 72.2 & $64.1 \pm 0.6$ \\
\hline & & Males & 37 & 6 & 19 & 10.0 & 59.2 & 73.0 & $66.2 \pm 0.5$ \\
\hline
\end{tabular}


Table 3. ANOVA results of statistical analyses to test differences in age structure and SVL at sexual and locality level. Statistically significant values are indicate by asterisks $\left({ }^{*}\right)$.

\begin{tabular}{cccc}
\hline \multicolumn{4}{c}{ Age Structure by Sex and Population } \\
\hline Factor & Degrees of freedom & $\mathbf{F}$ & Probability $>$ F \\
Sex & 1 & 8.6671 & $0.0034^{*}$ \\
Locality & 8 & 74.9023 & $<0.0001^{*}$ \\
Locality $\times$ sex & 8 & 2.4706 & $0.0128^{*}$ \\
& SVL by sex and population & \\
Factor & Degrees of freedom & $\mathbf{F}$ & Probability $>$ F \\
Locality & 8 & 62.6399 & $<0.0001^{*}$ \\
Sex & 1 & 10.2254 & $0.0015^{*}$ \\
Locality $\times$ sex & 8 & 6.3897 & $<0.0001^{*}$ \\
\hline
\end{tabular}

Age at sexual maturity ranged from 4 to 9 years among populations. The lacustrine populations of Perramó and Acherito, and the stream-dwelling population near Acherito matured earlier than the others. In all the examined populations, age at sexual maturity was similar between sexes, or the females matured at younger age than males, the only exception was the Espeluchieca lake population (Table 2). Maximum longevity varied from 7 to 35 years among populations and correlated with the age of sexual maturity $(\mathrm{r}=0.821, p=0.010, n=9)$. Although maximum longevities were correlated between sexes $(\mathrm{r}=0.762, p=0.016, n=9)$, populations differed in the sexual pattern of longevity, males tending to develop high longevity. That was the case of the lacustrine populations, although it was also found in half of the rheophilous populations.

Body size significantly differed among populations (locality: $\mathrm{F}_{8381}=62.639, p<0.001$ ) and was sexually dimorphic (sex: $F_{1381}=10.225, p=0.002$ ) (Figure 3, Table 2). Body size variation was not related to the kind of habitat of the populations (Table 2). Smallest mean body sizes for both sexes corresponded to the Oto population, and the largest to the Barranc Acherito populations. The other populations showed intermediate values. Except in two stream localities, males show a larger mean body size than females. For example, the smallest and largest mean body sizes corresponded to stream-dwelling populations while lacustrine newts showed intermediate values. Regarding the maximum values, there was also not a clear association with habitat. Although in most populations males showed higher mean values than females, this latter sex reached higher maximum sizes in some cases. As a result, the pattern of sexual dimorphism was not the same for all the populations $\left(\mathrm{F}_{8381}=6.389, p<0.001\right)$ (Table 3) and was not related to the habitat.

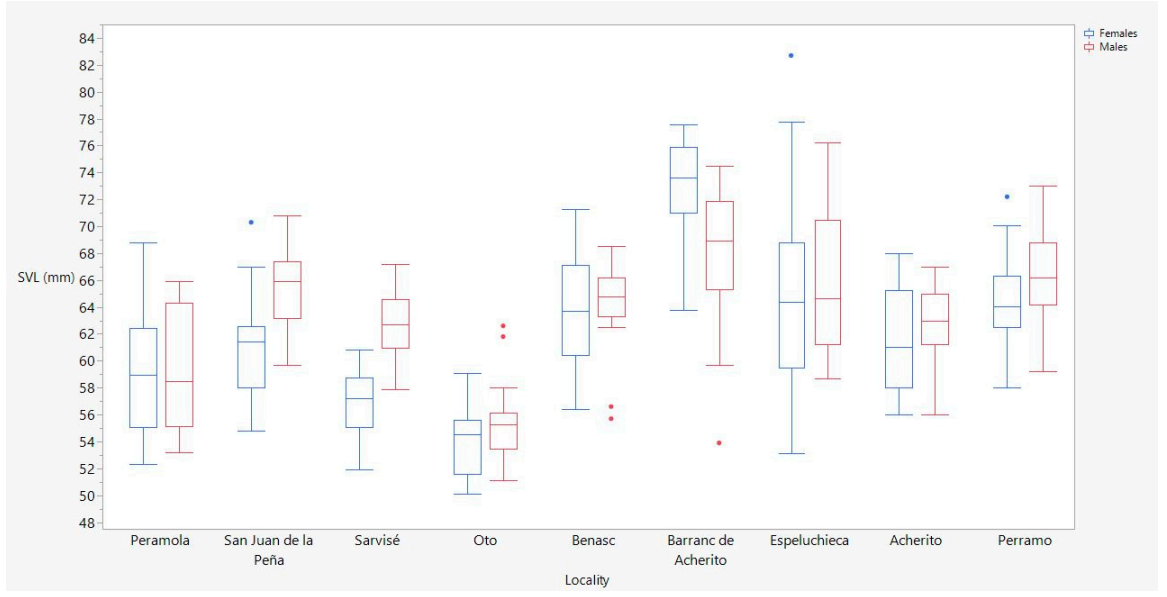

Figure 3. Box-plot of the snout-vent length of the newts for each locality and sex. The 1st Quartile (values up to the first $25 \%$ of sample) lower box limit and the 3rd Quartile (values up to $75 \%$ of sample) upper box limit. Vertical stripes outside the box identify the maximum and minimum values. The extreme cases are represented by circles. 


\section{Discussion}

Variability in life history traits of amphibians is a result of adaptations to different environmental conditions. In our case, despite the clear differences in ecological conditions between rheophilous and lacustrine environments [28], experienced by Calotriton asper, our results showed a complex picture where the interactions of multiple factors, not linked with the habitat conditions, determine the demographic traits of populations. Consequently, life history traits such as age at maturity and longevity can show a variation with habitat, molded by its specificities [29]. We suggest that the environmental factors explain variation in life history traits, body size, and growth rates. This variation can be related to water temperature, annual duration of the activity period, foraging activity, and the duration of the terrestrial phase [20].

Observing the species distribution, glaciations could have limited the persistence of populations of Calotriton asper in lakes before the end of the last glaciation, so the origin of these would be recent colonization [30]. Quaternary glacial events, with expansion-contraction of the geographic range, have influenced and explain the current distribution of Pyrenean fauna and flora [31,32]. Although the habitats trace the great ecological lines, it is the peculiarities of each locality that define aquatic and terrestrial conditions such as the temperature, predation pressure, structure, and trophic productivity or competition with other species [3]. The different "life history traits and body size" found in the localities could be a reflex of the environmental and climatic forces that act on them. These strategies are directly influenced by the duration of the annual activity period and the duration of the terrestrial and larval phases [33]. Age or size at metamorphosis, at maturity, and longevity, result from trade-offs between advantageous conditions in environments [34]. All stream dwelling populations showed intermediate age structure among the lacustrine localities, singular conditions of each locality influences in a different way in the demography of each one of the populations. The great majority of the lakes of the Pyrenees are not populated by Calotriton asper, the difficult colonization of lacustrine habitats causes changes in the demography since most of them do not have the ideal biotic and abiotic conditions. The only two localities with facultative pedomorphosis, Acherito and Perramó, are characterized for not having an immature terrestrial phase, likely increasing the population density in the lake. It seems that the peculiarities in the conditions of these lakes have allowed the development of a pedomorphic phenotype $[16,17,21]$. In these lakes, the populations show a first sexual maturity to compensate for short longevity. The benefits of early maturation are a shorter generation time, reducing exposure to juvenile mortality [4]. In contrast, the lacustrine population of Espeluchieca delays the age of sexual maturity, reaching greater longevity and larger body size. In this population, newts live together with fishes, which share the lake but there is spatial segregation between them (personal observation F. Amat). This spatial segregation is formed on a slope of the lake, where the rocks from the landslides are submerged into the water, making a physical separation. It is known that the aquatic shelters favor coexistence between newts and fish [35]. We can also see the pressure of the fish on the newts when they live together in the stream population of Barranc Acherito, where there is short longevity and early maturity, which could be due to the presence of fish. The smaller body sizes are for the localities of Sarvisé and Oto, although they have high longevity. There is possibly a strict selection for small body individuals that can hide from floods [36], because the number and dimensions of refuges such as stones and fissures define the density and distribution of newts [37]. In Calotriton asper annual active life varies from 4 to 8 months or more [13], also the duration of the larval phase varies from 1 to 3 years or more [16,38]. We do not know water temperature or variations in trophic conditions for the Calotriton asper populations that we studied. We can, however, hypothesize that environmental conditions are the inductors of this variability, which favors its adaptation. In several urodeles, the average age, age at maturity, and body size increase as the annual activity period shortens [39]. In the duration of the terrestrial phase, there seems to be a tendency to shorten in the lacustrine habitat or does not exist in pedomorphic populations.

In summary, the results of this study show that Calotriton asper exhibits interpopulation variability in the demography that does not depend on the habitat. In conclusion, we reject the hypothesis that 
habitat (stream and lake) gives a pattern to the demography in Calotriton asper. The factors that shape the demographics of populations have an effect on a smaller scale, differently within each locality beyond whether the habitat is rheophilous or lacustrine.

Author Contributions: Conceptualization, S.C., N.O., D.S. and F.A.; methodology, S.C., N.O., D.S. and F.A.; software, S.C., N.O. and F.A.; validation, S.C., N.O., D.S. and F.A.; formal analysis, S.C., N.O. and F.A.; investigation, S.C., N.O., D.S. and F.A.; resources, S.C., D.S. and F.A.; data curation S.C. and F.A.; writing-original draft preparation, S.C.; writing-review and editing, S.C., N.O., D.S. and F.A.; visualization, S.C., N.O., D.S. and F.A.; supervision, S.C., N.O., D.S. and F.A.; project administration, S.C., N.O., D.S. and F.A.; funding acquisition, S.C. and D.S. All authors have read and agreed to the published version of the manuscript.

Funding: This research was funded by the Biodiversity Conservation Plan of ENDESA, S.A. (ENEL Group).

Conflicts of Interest: The authors declare no conflict of interest. The funders had no role in the design of the study; in the collection, analyses, or interpretation of data; in the writing of the manuscript, or in the decision to publish the results.

\section{References}

1. Begon, M.; Harper, J.L.; Townsend, C.R. Ecology. Individuals, Populations and Communities; Blackwell Scientific Publications: London, UK, 1986.

2. Sorci, G.; Clobert, J.; Belichon, S. Phenotypic plasticity of growth and survival in the common lizard Lacerta vivipara. J. Anim. Ecol. 1996, 65, 781-790. [CrossRef]

3. Wilbur, H.M.; Collins, J.P. Ecological aspects of amphibian metamorphosis: Nonnormal distributions of competitive ability reflect selection for facultative metamorphosis. Science 1973, 182, 1305-1314. [CrossRef] [PubMed]

4. Stearns, S.C. Life history evolution: Successes, limitations, and prospects. Naturwissenschaften 2000, 87, 476-486. [CrossRef] [PubMed]

5. Adolph, S.C.; Porter, W.P. Growth, seasonality, and lizard life histories: Age and size at maturity. Oikos 1996, 77, 267-278. [CrossRef]

6. Oromi, N.; Valbuena-Ureña, E.; Soler-Membrives, A.; Amat, F.; Camarasa, S.; Carranza, S.; Sanuy, D.; Denoël, M. Genetic structure of lake and stream populations in a Pyrenean amphibian (Calotriton asper) reveals evolutionary significant units associated with paedomorphosis. J. Zool. Syst. Evol. Res. 2018, 57, 418-430. [CrossRef]

7. Falconer, D.S.; Mackay, T.F.C. Introduction to Quantitative Genetics; Longman: Harlow, UK, 1996.

8. Colleoni, E.; Denoël, M.; Padoa-Schioppa, E.; Scali, S.; Ficetola, G.F. Rensch's rule and sexual dimorphism in salamanders: Patterns and potential processes. J. Zool. 2014, 293, 143-151. [CrossRef]

9. Selander, R.K. Sexual dimorphism and differential niche utilization in birds. Condor 1966, 68, $113-151$. [CrossRef]

10. Dobson, F.; Wigginton, J.D. Environmental influences on the sexual dimorphism in body size of western bobcats. Oecologia 1996, 108, 610-616. [CrossRef]

11. Frafjord, K.; Stevy, I. The red fox in Norway: Morphological adaptation or random variation in size? Z. Säugetierkunde 1998, 63, 16-25.

12. Miaud, C.; Merilä, J. Local adaptation or environmental induction? Causes of population differentiation in alpine amphibians. Biota 2001, 2, 31-50.

13. Clergue-Gazeau, M.; Martinez-Rica, J.P. Les différents biotopes de l'urodèle pyrénéen, Euproctus asper. Bull. Soc. Hist. Nat. Toulouse 1978, 114, 461-471.

14. Bruce, R.C. Life histories. In Reproductive Biology and Phylogeny of Urodela; Sever, D.M., Ed.; Science Publisher: Enfield, CT, USA, 2003; Volume 1, pp. 477-526.

15. Serra-Cobo, J.; Uiblein, F.; Martinez-Rica, J.P. Variation in sexual dimorphism between two populations of the Pyrenean salamander Euproctus asper from ecologically different mountain sites. Belg. J. Zool. 2000, 130, 39-45.

16. Camarasa, S.; Amat, F.; Sanuy, D.; Oromi, N. The occurrence of facultative paedomorphosis in a lacustrine population of the Pyrenean newt (Calotriton asper) morphology and age structure. J. Nat. Hist. 2018, 52, $33-34$. [CrossRef] 
17. Oromi, N.; Amat, F.; Sanuy, D.; Carranza, S. Life history trait differences between a lake and a stream-dwelling population of the Pyrenean brook newt (Calotriton asper). Amphib. Reptil. 2014, 35, 53-62. [CrossRef]

18. Montori, A. Skeletochronological results in the pyrenean newt Euproctus asper (Dugès, 1852) from one prepyrenean population. Ann. Sci. Nat. Zool. Paris 1990, 13, 209-211.

19. Guerrero-Campo, J. Variación altitudinal y dimorfismo sexual en la coloración y biometría del tritón pirenaico (Euproctus asper, amphibia-salamandridae). Lucas Mallada 1995, 7, 213-225.

20. Miaud, C.; Guillaume, O. Variation in age, body size and growth among surface and cave-dwelling populations of the Pyrenean newt, Euproctus asper (Amphibia; Urodela). Herpetologica 2005, 61, 241-249. [CrossRef]

21. Valbuena-Ureña, E.; Oromi, N.; Soler-Membrives, A.; Carranza, S.; Amat, F.; Camarasa, S.; Denoël, M.; Guillaume, O.; Sanuy, D.; Loyau, A.; et al. Jailed in the mountains: Genetic diversity and structure of an endemic newt species across the Pyrenees. PLoS ONE 2018, 13, e0200214. [CrossRef]

22. Puig, M.A.; Ventura, M. Arroyos y ríos de Alta Montaña. Boletín Life+limnopirineus 2016, 3, $2-4$.

23. Catalan, J.; Camarero, L.; Felip, M.; Pla, S.; Ventura, M.; Buchaca, T.; Bartumeus, F.; De Mendoza, G.; Miró, A.; Casamayor, E.O.; et al. High mountain lakes: Extreme hábitats and witnesses of environmental chances. Limnetica 2006, 25, 551-584.

24. Miaud, C. La squelettochronologie chez les Triturus (Amphibiens, Urodeles) à partir d'une étude de $T$. alpestris, T. helveticus et T. cristatus du sud-est de la France. In Tissus Durs et Age Individuel des Vertébrés; Baglinière, J.L., Castanet, J., Conand, F., Meunier, F.J., Eds.; ORSTOM-INRA: Paris, France, 1991.

25. Amat, F.; Oromi, N.; Sanuy, D. Body size, population size, and age structure of adult Palmate newts (Lissotriton helveticus) in Pyrenean Lakes. J. Herpetol. 2010, 44, 313-319. [CrossRef]

26. Morrison, C.; Hero, J.M. Altitudinal variation in growth and development rates of Litoria chloris and Litoria pearsoniana tadpoles in southeast Queensland, Australia. J. Herpetol. 2003, 37, 59-64. [CrossRef]

27. JMP, Version Pro 14; SAS Institute Inc.: Cary, NC, USA, 1989-2019.

28. Elser, J.J.; Wu, C.; González, A.L.; Shain, D.H.; Smith, H.J.; Sommaruga, R.; Williamson, C.E.; Brahney, J.; Hotaling, S.; Vanderwall, J.; et al. Key rules of life and the fading cryosphere: Impacts in alpine lakes and streams. Glob. Chang. Biol. 2020, 26, 6644-6656. [CrossRef] [PubMed]

29. Roff, D. Trade-offs between growth and reproduction: An analysis of the quantitative genetic evidence. J. Evol. Biol. 2000, 13, 434-445. [CrossRef]

30. Lucati, F.; Poignet, M.; Miró, A.; Trochet, A.; Aubret, F.; Barthe, L.; Bertrand, R.; Buchaca, T.; Calvez, O.; Caneret, J.; et al. Multiple glacial refugia and contemporary dispersal shape the genetic structure of an endemic amphibian from the Pyrenees. Mol. Ecol. 2020, 29, 2904-2921. [CrossRef] [PubMed]

31. Jalut, G.; Montserrat-Marti, J.; Fontugne, M.; Delibrias, G.; Vilaplana, J.M.; Julia, R. Glacial to interglacial vegetation changes in the northern and southern Pyrénées: Deglaciation, vegetation cover and chronology. Quat. Sci. Rev. 1992, 11, 449-480. [CrossRef]

32. Taberlet, P.; Fumagalli, L.; Wust-Saucy, A.G.; Cosson, J.F. Comparative phylogeography and postglacial colonization routes in Europe. Mol. Ecol. 1998, 7, 453-464. [CrossRef] [PubMed]

33. Whiteman, H.H. Evolution of facultative paedomorphosis in salamanders. Quat. Rev. Biol. 1994, 69, $205-221$. [CrossRef]

34. Denoël, M. Terrestrial versus aquatic foraging in juvenile Alpine newts (Triturus alpestris). Écoscience 2004, 11, 404-409. [CrossRef]

35. Winandy, L.; Darnet, E.; Denoël, M. Amphibians forgo aquatic life in response to alien fish introduction. Anim. Behav. 2015, 109, 209-216. [CrossRef]

36. Montori, A.; Richter-Boix, A.; Franch, M.; Santos, X.; Garriga, N.; Llorente, G.A. Natural fluctuations in a stream dwelling newt as a result of extreme rainfall: A 21-year survey of a Calotriton asper population. Basic Appl. Herpetol. 2012, 26, 43-56. [CrossRef]

37. Montori, A.; Llorente, G.A.; Richter-Boix, A. Habitat features affecting the small-scale distribution and longitudinal migration patterns of Calotriton asper in a Pre-Pyrenean population. Amphib. Reptil. 2008, 29, 371-381. [CrossRef]

38. Clergue-Gazeau, M.; Beetschen, J.C. Contribution à l'étude de la reproduction de l'Urodèle Euproctus asper (Dugès) dans les Pyrénées centrales et Ariègeoises. Ann. Limnol. Int. J. Limnol. 1966, 2, 217-226. [CrossRef] 
39. Miaud, C.; Guyétant, R.; Faber, H. Age, size and growth of the alpine newt, Triturus alpestris (Urodela, Salamandridae), at high altitude and a review of life-history trait variation throughout its range. Herpetologica 2000, 56, 135-144.

Publisher's Note: MDPI stays neutral with regard to jurisdictional claims in published maps and institutional affiliations.

(C) 2020 by the authors. Licensee MDPI, Basel, Switzerland. This article is an open access article distributed under the terms and conditions of the Creative Commons Attribution (CC BY) license (http://creativecommons.org/licenses/by/4.0/). 